\title{
Role of Social Media in the Promotion of 'Hidden Canyon' Tourism Object
}

\author{
Ni Wayan Rena Mariani, Firlie Lanovia Amir \\ Hospitality Management \\ Sekolah Tinggi Pariwisata Bali \\ Denpasar, Indonesia \\ wynrena@stpbi.ac.id
}

\begin{abstract}
In tourism sectors, social media used by tourism stakeholder to market the tourism product and build relationship with customer. Social media plays a vital role in tourim marketing and spreading information. Social media introduces several new tourism objects to the public. One of the tourism objects is the "Hidden Canyon" located in Sukawati districts, Gianyar Regency, Bali province. This study discuss about promotion through social media and its role in introducing 'Hidden Canyon' to the public and using questionnaire that is filled by the visitors, this study deals on the origin of the visitors and how they were introduced to this tourism object. Interview technique was also used to gain data from several natives and the village chief to complement the data in regards of marketing management of the 'Hidden Canyon'. The result of this study shows that the promotion of this tourism object was not professionally managed by either the leaders of the area or the local community. The 'Hidden Canyon' was introduced to the public through social media of Instagram, Facebook, YouTube, and several others. Visitors that came to the object shares their information in social media, so that the information of Hidden Canyon spreads widely in the public.
\end{abstract}

Keywords- Social Media Marketing, Promotion, Hidden Canyon Bali

\section{INTRODUCTION}

Social media is currently a trend. From younger people to older professional used social media as a way to share their life to the community. Every activity, every idea, shared through words composition or pictures.

This habit of sharing makes social media as an effective source of information. Many things can be shared through social media. Starts with a simple insignificant issue, to the most important issue in history. The reasons they 'share' are various. One among the reasons is that to gain the attentions of the community while others shared what is trending so they look 'up to date'.

Social media became the most effective information distribution media due to the 'sharing' habit. Information shared by a user can be a trend and this makes it is very easy to promote an existing product or a new product. Currently, social media is the most important promotion media to marketing industry.
Social Networking is a technology that let the people to communicate, and share information online (Waad Assaad, 2011). In Indonesia, Social Networking called 'media sosial'. Several social media that commonly used is Facebook, Instagram, Path, Twitter, and Youtube.

Social media turns out to be an important part in marketing. It enables potential customerto interact with the producer of the goods or the distributors of the product.

Since a few years back, social media replace traditional marketing tools that commonly used prior to the information age. The traditional method is no longer effective for this era. According to Sajid (2016_, international companies states that the potential promotion system for their company is through social media.

In the Research of Neti(2011) states that social media enable business owner to: a). Shares knowledge and skill of running the business. b). Knowledge of their customer needs. c). One customer can help other customer. d) Engaging potential customer. Social media makes business owners to be known by their future customers and their customers as well as the quality of the product and the ability of the business owner to serve them.

This research concludes that the role of social media in marketing is extremely important. Several role of the social media in marketing are as stated: a) as information supplier in regards of the company and product or the service offered by the business owners to the customers. b) as a media to build a relationship between costumers and the community so that the community who have no knowledge of the product or service of the business owner able to gain information of the product or service. c) As a media that able to make costumers feel more intimate to the business because business owners not only share about their new product but also anything that related to their business. d) As a media that bring together business owners. They can share knowledge on owning business that may serve the common market segment. e) as a communication media for customers. Customers can interact to each other regarding the product or service they need.

Generally, the role of social media stated above connects costumers with costumers, costumers with business owners, business owners to other business owners. 
The role of social media also affecting tourism industry. The marketing method of tourism industry affected by the development of social media.

Makes unknown destinations to be known by the public. Many hotels and restaurants that less known by the public become the favorite and most visited due to the 'posts' in social media. Several places that have their own uniqueness became a tourism destination due to the post in social media. This is what had happened to Hidden Canyon Tourist Object in Guwang Sukawati Gianyar.

The Hidden Canyon is a natural tourism object of cliffs at the side of a river. To get to the object, visitors need to walk in the middle of the river and against the stream for 500 meters. There are three spots that are favorites for the visitors to take pictures. The local guide call it canyon one, canyon two, and canyon three.

The Hidden Canyon originally is a river that is used by the village native to take a bath and fishing. There is a Hindu temple in the river that is used by the villager. Currently, it is the most wanted tourism object to be visited by the tourist, foreign and domestics. Since the end of 2015 visitors began to come to this place to enjoy the beauty themselves.

One of the local guide named Wayan Darma said that Hidden Canyon Tourism Object starts to get famous due to a post of a friend of a Guwang villager that was fishing there at that time. That picture then posted to the Instagram account. Since then, many visitors came to enjoy the beauty of the canyon. Every visitor take pictures and share them through their own social media. This resulted in more and more visitors came to see the beauty of this object.

Based on the description of the facts above, there are several issues that can be identified. 1).How is the strategy of the community and the village officials to promote The Hidden Canyon? 2).How is the role of social media in promoting Hidden Canyon Tourism Object?

\section{MetHODS}

The study was conducted in the location of Hidden Canyon Tourism Object. The study involves visitors, management of the object, and the guide that work in the object. The data needed in this study was taken from visitors, management and the guides.

The study used qualitative and quantitative as primary data. Method used to collect the primary data is questionnaire and interview.

Secondary data in form of the increase of visit and data from social media needed in this study. Method used to gather secondary data is documentation and online data search method. (bungin, 2007)

Questionnaires are given to 60 visitors that randomly chosen in different days. Questionnaire data taking starts from early August 2016 to early October 2016. There were 9 questions need to be answered by respondents. The first 4 questions to identify the activity of respondents in using social media. The 5 remaining questions to determine the role of social media in distributing information on Hidden Canyon

Interview method is used to dig further on the role of social media in promoting Hidden Canyon. Interview was conducted to four local guidesto dig deeper on the beginning of the visitors came to Hidden Canyon.

Online data research conducted to determine the most common type of social media used to promote Hidden Canyon. This method also used to determine what were the messages in the social media and how many messages or article that used to promote the Hidden Canyon.

\section{RESULT}

The Hidden Canyon located in Guwang Village, Sukawati Disrict, Gianyar Regency, Bali Province.The beauty of this object is the beatiful view of the cliffs at the both side of the river.To see the beautiful view, visitors need to walk in the river as long as two kilometers.

There are three locations that owns a most stunnning cliffs view.The first location is canyon 1 . Canyon 1 is an area that owns a cliff as high as 30 meters. This cliff streches along the side of the river as far as 50 meters. In this area the width of river is about 4 meter. Canyon 1 can be found by visitors if the visistors had walk the river upstream as far as 500meters.During the trips visitors will see a lot of rocks along the river.

The second location is called canyon 2 located 500 meters further from the first location. The beauty of the second location had no difference to the first.But the cliff that streches on the second location is shorter. Second location is close with third location that is called canyon 3. Figure 1 shows the landscape of Canyon.

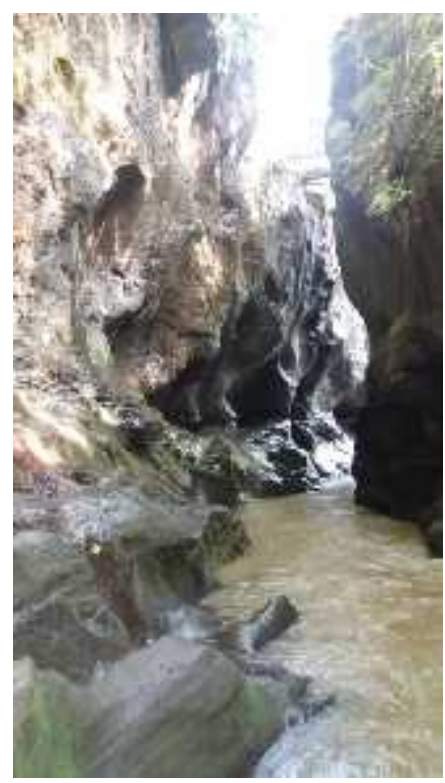

Fig. 1. Landscape of canyon 
Visitors that came and wanted to enjoy the three locations need to be accompanied by a local guide. The guide will accompany visitors down the river to reach the location of the Hidden Canyon. It is mandatory for visitor to use the service of the guide. It caused by the dangerously slippery way that need to be taken by the visitors. Each guide responsible to handle 3 visitors. If the group of visitors consists of more than 3 persons, then, 2 guides are needed to accompany the group. It is a mandatory code of conduct.

To enjoy the Hidden Canyon, visitors need to pay a registration as much as Rp. 10.000 . This registration named as a Donation by the management team and the nominal can be determined by the visitors. As an expression of gratitude, visitors usually give tips to the guide that accompany them along the way down the river and back to the registration spot. The amount can be varied. Starts from Rp. 50.000 up to Rp. 300.000 for one trip along the river.

The registration spot is a semi-permanent building. It is equipped with a table, chairs, lockers to store visitor's belongings and 4 toilets that also can be used to change clothes.

The Hidden Canyon is a new tourism destination so that the management is also still very simple. The management team consists of the people chosen by the village officials. They responsible in managing the object. The team had no planning in running the object. They simply did not determine any target market of visitors.

The management team also don't have any plan in running the marketing. The team only create an account in facebook and instagram as a media to promote the object. The account is named Hidden Canyon Tukad beji Guwang.

Both of this account filled with photos that pictures the beauty of the hidden canyon. The comments in the photo is not much. The comments came mostly from other accounts that sees the photos.

The management model that is simple caused a drawback in data collection. Crucial data of visits was not run seriously. The daily visits data only available from the beginning of 2016 while the visitors had come to the object at the last quarter of 2015. The visits count method is not using the entry ticket. They merely count from the money earned from the donations of the visitors.

Figure 2 shows the graphic that pictures the visits count to hidden canyon from January 2016 until September 2016.

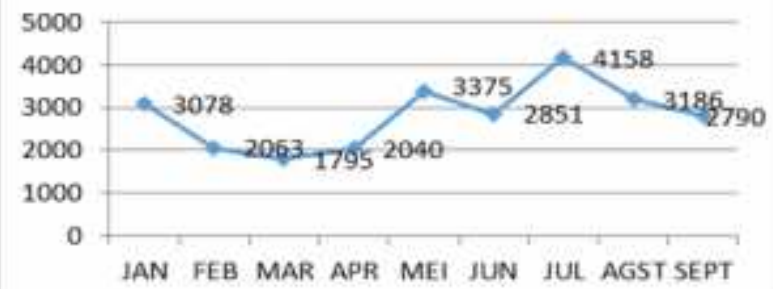

Fig. 2. The Respondent's Age
The above data was supported by the result of interview conducted to two local guide. Bayu Krisna and Wayan Darma states that the average visitors that came to hidden canyon range from 30 to 100 persons per day.

The interview results with the two guide make it clear that the common social media used by the visitor to share their post is facebook and instagram. Both of this social media used by visitors to share photos that capture the beauty of Hidden Canyon. Visitors also put captions on the photos they uploads to the social media.

Another supporting data is the data gained from the questionnaire. The questionnaire was given to the visitors in the location. The respondents age range from 17 to 45 years old. Figure 3 shows the percentage diagram of age group.

The highest education level of the visitors is 'High school and above'. Respondent is an active users of social media. Respondents had been using social media for at least one year. Respondents own at least 100 friends in social media.

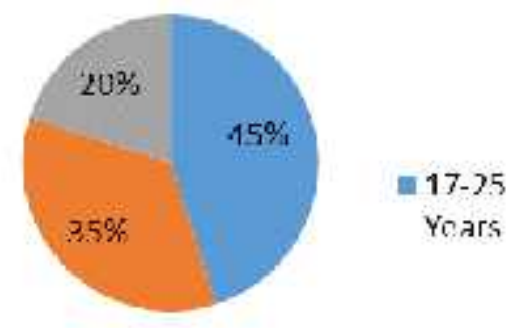

Fig. 3. The Respondent's Age

Through questionnaire, respondents that used social media more than 1 hour daily states that they learn of Hidden Canyon from social media. $60 \%$ of the visitors admits that they know Hidden Canyon from social media, 30\% others states that they know hidden canyon from friends and another $10 \%$ states that they know Hidden Canyon from other sources such as drivers that accompanied visitors during their visits in Bali. Figure 4 shows the diagram that stated the source of information received by the respondents.

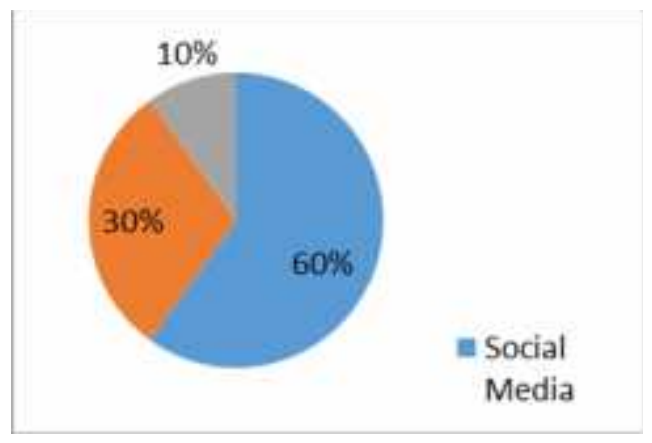

Fig. 4. Source of information about hidden canyon

Information in social media is in form of photos and captions that explains the photos. Respondents states that this 
information that really makes them wanted to visit Hidden Canyon.

The active social media users respondents states that only saw the article in social media less than 5 times. The social media that is used is Facebook, Twitter, Instagram, Youtube, and blogger.com.

Based on the data analysis above, it can be determined that the use of social media to promote the Hidden Canyon has not been done optimally. This resulted from the less serious management of the two social media account owned by the management of Hidden Canyon. Many information in form of photos or comments made by social media users that was tagged back to Hidden Canyon Tukad Beji Guwang account. The administrator of the account has not been giving sufficient and updated sustainable information. The post that shared by this account is not been done continually. This resulted in many of social media users were not updated on the information of Hidden Canyon.

The role of social media in the promotion of tourism object is only the media to establish a connections between visitors and the community who have not visited the object. The general public that have not been to the object may get the information from social media that there is a tourism object in Guwang Village, Sukawati, Gianyar named Hidden Canyon..

Besides the role stated above, social media also acts as a bridge that connects visitors from one to another. The connections is needed to deliver the latest information available in the field due to the rapid changes of the water level of the river that may be too dangerous for visitors to walk in. This also makes some visitors to feel obliged to repeat their visit if they fail to enjoy the hidden canyon the first time.

\section{CONCLUSION}

The management team of Hidden Canyon use social media as one strategy to promote the Object. The social media used is Facebook and Instagram. But both of this account has not been fully utilized.

Both social media account need to be managed seriously. Updating the information need to be done continuously by the administrator of the account. The information posted in social media need to be planned in detail. The post that had planned had a purpose to increase the interest of social media users to visit the object.

The role of social media to promote the Hidden Canyon as a tourism object is pretty good. The roles are a). Media to build connections between visitors and the general public that have not been visiting the object. And b). Media that connects visitor to another visitors.

The management to run the Hidden Canyon tourism object need to be done seriously. The related party in this problem is Gianyar regency tourism office and village officials of Guwang.

The stated party should coordinate in the management of data, infrastructure, service and marketing. The management needs to be given an accompaniment of experts in running the Hidden Canyon tourism object.

\section{REFERENCE}

Bungin, B. (2007). Penelitian kualitatif. Jakarta: Prenada Media Group.

Creswell, J. W. (2009). Research Design. California: Sage publications.

Dave Evans, J. M. (2010). Social Media Marketing. Indianapolis: Wiley Publishing Inc.

Fractl. (2016, April). Facebook Sharing Motivation . citated on September 17, 2016, from Fractl-Reasearch: http://www.frac.tl/research/facebook-sharing-motivations

Khosrow-Pour, M. (2013). Dictionary of Information Science and Technology. USA: IGI Global.

Neti, S. (2011). Social media and its role in marketing. International Journal of enterprise computing and Bussiness system .

Sajid. (2016). Social Media and its Role in Marketing. Business and Economics Journal .

Waad Assaad, J. M. (2011). Social Network in Networking Opportunities and Risks. International Journal of Managing Public sector Information and Communication Technologies . 